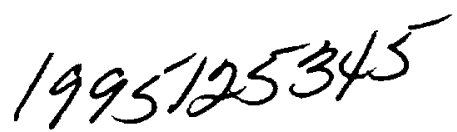

N95-31766

\title{
Evaluation of HFC 245ca and HFC 236ea as Foam Blowing Agents
}

\author{
J. Sharpe, D. MacArthur \\ Martin Marietta Manned Space Systems \\ Marshall Space Flight Center, Alabama
}

T. Kollie, R. Graves

Oak Ridge National Laboratory

Metals and Ceramics Division

Oak RIdge, Tennessee

\author{
M. Liu \\ Martin Marletta Manned Space Systems \\ New Orleans, Loulsiana \\ R. Hendriks \\ U.S. Environmental Protection Agency \\ Air and Energy Engineering Research Laboratory \\ Research Trlangle Park, North Carolina
}

\begin{abstract}
Hydrochlorofluorocarbon (HCFC) $141 \mathrm{~b}$ has been selected as the interim blowing agent for use in urethane insulations on NASA's Space Shuttle External Tank. Due to the expected limited commercial lifetime of this material, research efforts at the NASA Thermal Protection Systems Materials Research Laboratory at the Marshall Space Flight Center are now being devoted to the identification and development of alternatives with zero ozone depletion potential. Physical blowing agents identified to date have included hydrocarbons, fluorocarbons, hydrofluoroethers, and more predominantly, hydrofluorocarbons (HFCs). The majority of the HFC evaluations in industry have focused on the more readily available, low boiling candidates such as HFC 134a. Higher boiling HFC candidates that could be handled at ambient conditions and use current processing equipment would be more desirable.
\end{abstract}

This paper will describe results from a research program of two such candidate HFCs performed as a cooperative effort between Martin Marietta Manned Space Systems, the U.S. Environmental Protection Agency, and Oak Ridge National Laboratories. The purpose of this effort was to perform a cursory evaluation of the developmental HFCs $245 \mathrm{ca}$ and $236 \mathrm{ea}$ as blowing agents in urethane based insulations. These two materials were selected from screening tests of $37 C_{2}, C_{3}$, and $C_{4}$ isomers based on physical properties, atmospheric lifetime, flammability, estimated toxicity, difficulty of synthesis, suitability for dual use as a refrigerant, and other factors. Solubility of the two materials in typical foam components was tested, pour foaming trials were performed, and preliminary data were gathered regarding foam insulation performance.

\section{INTRODUCTION}

Hydrochlorofluorocarbon (HCFC)-141b has been widely adopted as the interim blowing agent of choice in rigid foam insulations. Even though this material has an Ozone Depletion Potential (ODP) approximately $85 \%$ lower than the chlorofluorocarbon (CFC)-11 it is targeted to replace, HCFC-141b is also planned to be phased out in favor of alternatives with zero ODP. Current regulatory timelines, per the U.S. Environmental Protection Agency Phase-out of Ozone Depleting Substances 1 , call for phaseout of HCFC$141 \mathrm{~b}$, beginning in the year 2002 . This situation poses a significant challenge to the polyurethane insulation industry since there are no readily available non-flammable, liquid alternatives which could easily replace the HCFC-141b. This, combined with the fact that the transition from CFC-11 to "near drop-in" HCFC-141b, has taken well over 5 years, indicates that development and commercialization of a suitable zero ODP physical blowing agent is already on a critical schedule.

There is a need for industry to identify and provide a concerted effort toward development of acceptable foam blowing agent(s) that will meet all environmental goals and provide permanent solutions to the blowing agent issue. Alternatives such as hydrocarbons, low boiling HFCs, and water/carbon dioxide have been shown to be suitable for some applications. For other applications, a non-flammable, liquid, physical blowing agent is more desirable. One source of potential zero ozone depleting blowing agents in this category is the new experimental chemicals being developed as proposed refrigerant altematives. Several such chemicals have been proposed by the Environmental Protection Agency (EPA) Air and Energy Engineering Research Laboratory (AEERL) as alternatives to CFC refrigerants based on having 
properties similar to those of CFC refrigerants. One of them, 1,1,2,2,3-pentafluoropropane (HFC-245ca), is being considered as a CFC-11 alternative for chillers, and another, HFC-236ea $(1,1,1,2,3,3$ -

hexafluoropropane), has been the subject of more extensive theoretical and experimental evaluation as a CFC-114 alternative for shipboard cooling. Both HFC-245ca and HFC-236ea have desirable properties

for use as foam blowing agents.

This paper presents results of a cooperative effort between the U.S. EPA, Oak Ridge National Laboratory, and Martin Marietta Manned Space Systems to evaluate HFC-245ca and HFC-236ea as blowing agents for rigid polyurethane insulation foams, and to perform cursory accelerated aging evaluations of hand poured samples. A third chemical, HFC-245fa, was also considered in this program, but was not evaluated experimentally due to difficulties in obtaining sufficient quantities for evaluation.

PROPERTIES OF HFC-245ca and HFC-236ea

Beyerlein et al. presented a technical paper ${ }^{2}$ listing the thermophysical properties of a number of new chemicals, including HFC-245ca and HFC-236ea. Additional properties of these materials supporting their potential use as blowing agents were provided by Smith. ${ }^{3}$ In addition to these data, Knopeck et al. ${ }^{4}$ reported both physical property data and results of foaming trials of four candidate zero ODP HFCs, including HFC-245ca and HFC-236ea. A comparison of some relevant properties of HFC-245ca and HFC-236ea with CFC-11 and HCFC-141b is presented in Table 1.

Table 1. Blowing Agent Physical Property Comparison

\begin{tabular}{l|cccc}
\hline Property & CFC-11 & HCFC-141b & HFC-245ca & HFC-236ea \\
\hline Molecular Weight & 137 & 117 & 134 & 152 \\
Boiling Point, ${ }^{\circ} \mathrm{C}$ & 23.8 & 32.1 & 24.4 & 6.2 \\
Ozone Depletion Potential & 1 & 0.12 & 0 & 0 \\
Atmospheric Lifetime, yrs & 60 & 10 & 6.4 & 6.2 \\
$\begin{array}{l}\text { Vapor Thermal Conductivity, } \\
\quad \text { Btu-in/hr-ft }{ }^{2}{ }^{\circ} \mathrm{F}\end{array}$ & 0.057 & 0.072 & 0.095 & 0.100 \\
$\begin{array}{l}\text { Heat of Vaporization, } \\
\quad \text { Btu/lb-mol }\end{array}$ & 10,700 & 11,200 & 12,563 & 11,537 \\
Flammability & none & slight & none & none \\
\hline
\end{tabular}

\section{FORMULATION APPROACH}

Because HFC-245ca and HFC-236ea are not commercially available, experimental samples are relatively expensive. The high cost of the samples limited the scope of this effort to cursory formulation, development, and testing of manually poured foam panels. Based on our experience with HCFC-141b, where substitution based on molecular weight ratios did not prove optimum, our initial approach was to evaluate the experimental blowing agents in an existing formulation at a 1:1 substitution for CFC-11. This existing formulation is a hand pourable formulation based on a sucrose initiated polyol that exhibits good adhesion from cryogenic temperatures $\left(-423^{\circ} \mathrm{F}\right)$ to approximately $300^{\circ} \mathrm{F}$. Initial trials with this formulation blown with HFC-236ea resulted in poor foam cell structure, and further attempts to characterize the blowing agents using this formulation were abandoned. A more basic, urethane type system was then formulated to serve as a control formulation to provide a simple comparison of blowing agent effects. The A component of the control formulation was polymeric methylene diphenyldiisocyanate (MDI) with a functionality of 2.7 and viscosity of $\sim 180 \mathrm{cp}$ ). The basic formulation of the B component for the control is outlined in Table 2. 
Table 2. B Component Formulation

\begin{tabular}{l|l||l}
\hline Constituent & Material & $\%$ of Formulation \\
\hline Polyol 1 & Aromatic amine & 62.7 \\
Polyol 2 & Low molecular wt. triol & 2 \\
Polyol 3 & High molecular wt. triol & 4 \\
Catalyst & DMCHA & 0.4 \\
Surfactant & Silicone glycol copolymer & 2 \\
Blowing Agent & --- & 28.9 \\
\hline
\end{tabular}

To blend the B component, a master batch containing everything but the blowing agent was prepared. This master batch was then split into three equal portions, one for each blowing agent. CFC-11 and HFC$245 \mathrm{ca}$ were added at $72^{\circ} \mathrm{F}$. The HFC-236ea cylinder was cooled to $35^{\circ} \mathrm{F}$ before addition to the $72^{\circ} \mathrm{F}$ master batch. Cooling the master batch to $35^{\circ} \mathrm{F}$ before HFC-236ea addition was also attempted, but the high viscosity of the polyol at that temperature made it difficult to achieve a uniform blend. The previously described method tumed out to be suitable because the HFC-236ea did not exhibit an appreciable evaporation rate, when left undisturbed, after being blended with the polyol components.

Both the HFC-245ca and HFC-236ea blended quite readily with mechanical agitation. Samples of the B component with blowing agent were left in glass bottles for a period of 3 months. The HFC-236ea blend showed no signs of separation after this period. The HFC-245ca blend exhibited slight separation at 3 months, but was easily redispersed with agitation.

\section{REACTIVITY EFFECTS}

Cup reactivities were performed with the control formulation. The reactivity of the HFC-245ca was performed with the A and B components at $72^{\circ} \mathrm{F}$. The initial attempt to evaluate HFC-236ea reactivity at ambient temperature resulted in frothing of the $B$ component and loss of blowing agent. In order to preclude blowing agent loss in the HFC-236ea formulation, the A component was maintained at $72^{\circ} \mathrm{F}$ and the B component was cooled to $35^{\circ} \mathrm{F}$. Control reactivities were performed with the CFC-11 formulation at both of these initial component temperatures. Results of these cup tests are summarized in Table 3.

Table 3. Cup Reactivities

\begin{tabular}{l|cc|cc}
\hline Property & CFC-11 & HFC-245ca & CFC-11 & HFC-236ea \\
\hline A/B Temperature, ${ }^{\circ} \mathrm{F}$ & $72 / 72$ & $72 / 72$ & $72 / 35$ & $72 / 35^{*}$ \\
Cream time, sec. & 18 & 16 & 31 & 17 \\
Gel time, sec. & 63 & 72 & 98 & 130 \\
Tack-free time, sec. & 90 & 103 & 143 & 158 \\
Rise time, sec. & 130 & 140 & 186 & 180 \\
Density, lb/ft ${ }^{3}$ & 1.9 & 1.7 & 1.9 & 1.8 \\
\hline
\end{tabular}

*Initial B component temperature was $35^{\circ} \mathrm{F}$ to preclude blowing agent loss. No catalyst adjustment was made to normalize reactivity.

These results show that the HFC-245ca has very similar reactivity characteristics to the CFC-11 control. The gel, tack-free, and rise times were approximately 8 to $14 \%$ longer with the HFC-245ca than with the 
CFC-11. It is expected that this is due merely to differences in the heat of vaporization in these materials, which could be easily accommodated by adjustments in catalyst level and/or component temperature. As anticipated, the HFC-236ea reactivity with an initial B temperature of $35^{\circ} \mathrm{F}$ was significantly slower than the CFC-11 with both components at $72^{\circ} \mathrm{F}$. However, when the reactivity of the CFC-11 system was evaluated with the A component at $72^{\circ} \mathrm{F}$ and the B component at $35^{\circ} \mathrm{F}$, the cream time of the HFC-236ea system was shorter than the CFC-11, while the gel and tack-free times were longer than the CFC-11 blown sample. The shorter cream time was expected due to the difference in boiling points of the two materials. The extended gel and tack-free times of the HFC-236ea are suspected to be partially attributable to the high solubility of the HFC-236ea.

Automated reactivity measurements were also made with the three blowing agents. Plots of foam reaction temperature and reaction height are presented in Figures 1 and 2, respectively. A comparison of the reaction temperatures of CFC-11 and HFC-245ca with the A and B component temperatures initially at $73^{\circ} \mathrm{F}$ shows that, after initiation of the reaction, the HFC-245ca exotherm begins to lag that of CFC- 11 . Comparison of CFC-11 and HFC-236ea with initial A and B component temperatures of $70^{\circ} \mathrm{F}$ and $35^{\circ} \mathrm{F}$, respectively, shows the same characteristic. This is expected due to the difference in heat of vaporization of the two blowing agents, and should be resolvable with a more optimized catalyst system.

In Figure 2, the foam reaction height profiles of CFC-11 and HFC-245ca with A and B temperatures initially at $73^{\circ} \mathrm{F}$, show very similar trends. Comparison of CFC-11 and HFC-236ea with A and B temperatures of $70^{\circ} \mathrm{F}$ and $35^{\circ} \mathrm{F}$, respectively, shows that the HFC-236ea begins to rise earlier and maintains a fairly constant rate of rise. The faster initial rise of the HFC-236ea blown foam is expected due to the low boiling point of the material.

\section{FOAM PROPERTIES}

\section{Free Rise Foam Characteristics}

Free rise samples of each foam were tested for various physical and mechanical properties, and results are presented in Table 4.

Table 4. Free Rise Foam Properties

\begin{tabular}{l|c|c|c}
\hline Property & CFC-11 & HFC-245ca & HFC-236ea \\
\hline $\begin{array}{l}\text { Density, lb/ft }{ }^{3} \\
\begin{array}{c}\text { Compressive Strength, } \\
\text { parallel to rise, lb/in }\end{array}\end{array}$ & 1.69 & 1.59 & 1.73 \\
$\begin{array}{c}\text { Compressive Strength, } \\
\text { perpendicular to rise, lb/in2 }\end{array}$ & 24 & 28 & 22 \\
$\begin{array}{c}\text { Flatwise Tensile Strength, } \\
\text { parallel to rise, lb/in }\end{array}$ & 61 & 8 & 11 \\
$\begin{array}{c}\text { Flatwise Tensile Strength, } \\
\text { perpendicular to rise, lb/in }\end{array}$ & 28 & 66 & 61 \\
Friability, \% mass loss & 4.1 & 25 & 35 \\
\hline
\end{tabular}

These values indicate that foams with approximately equivalent properties can be prepared using the three different blowing agents.

Micrographs of free rise foam samples were prepared as a preliminary comparison of foam cell structure. These micrographs, presented in Figures 3 through 5, show that the HFC-245ca had a cell size and cell size distribution similar to CFC-11, and the HFC-236ea exhibited a slightly finer, more uniform cell structure. 


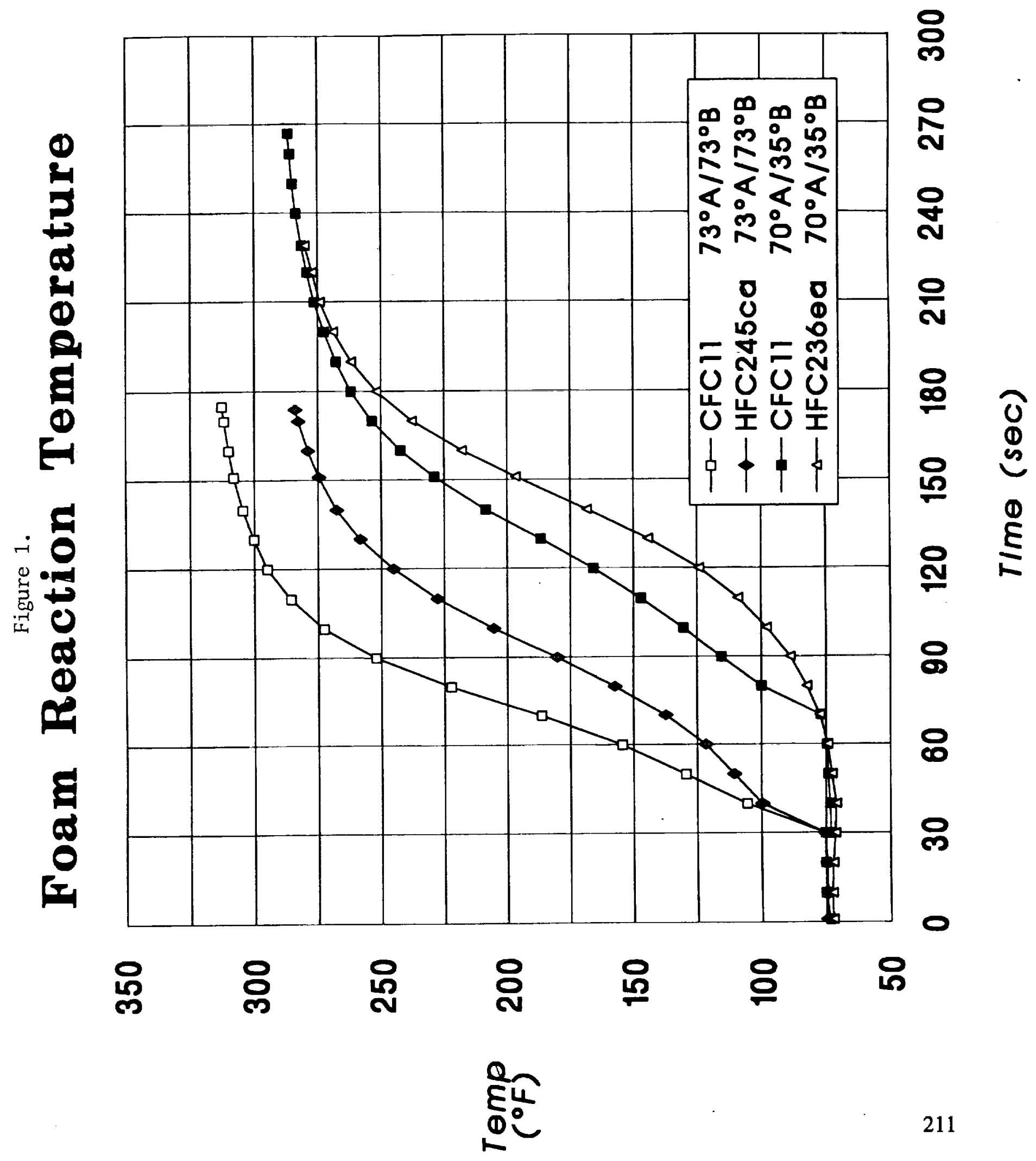




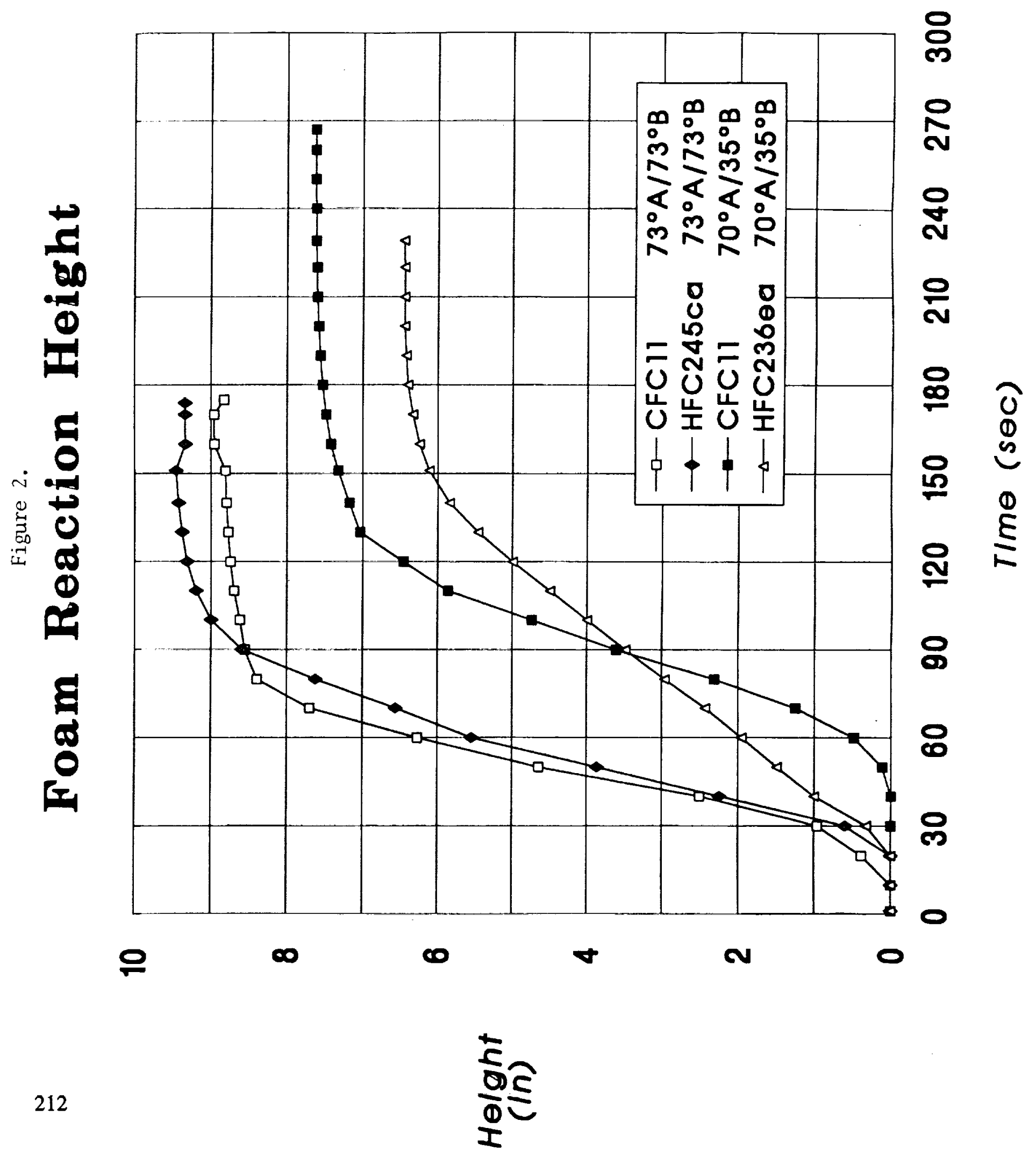




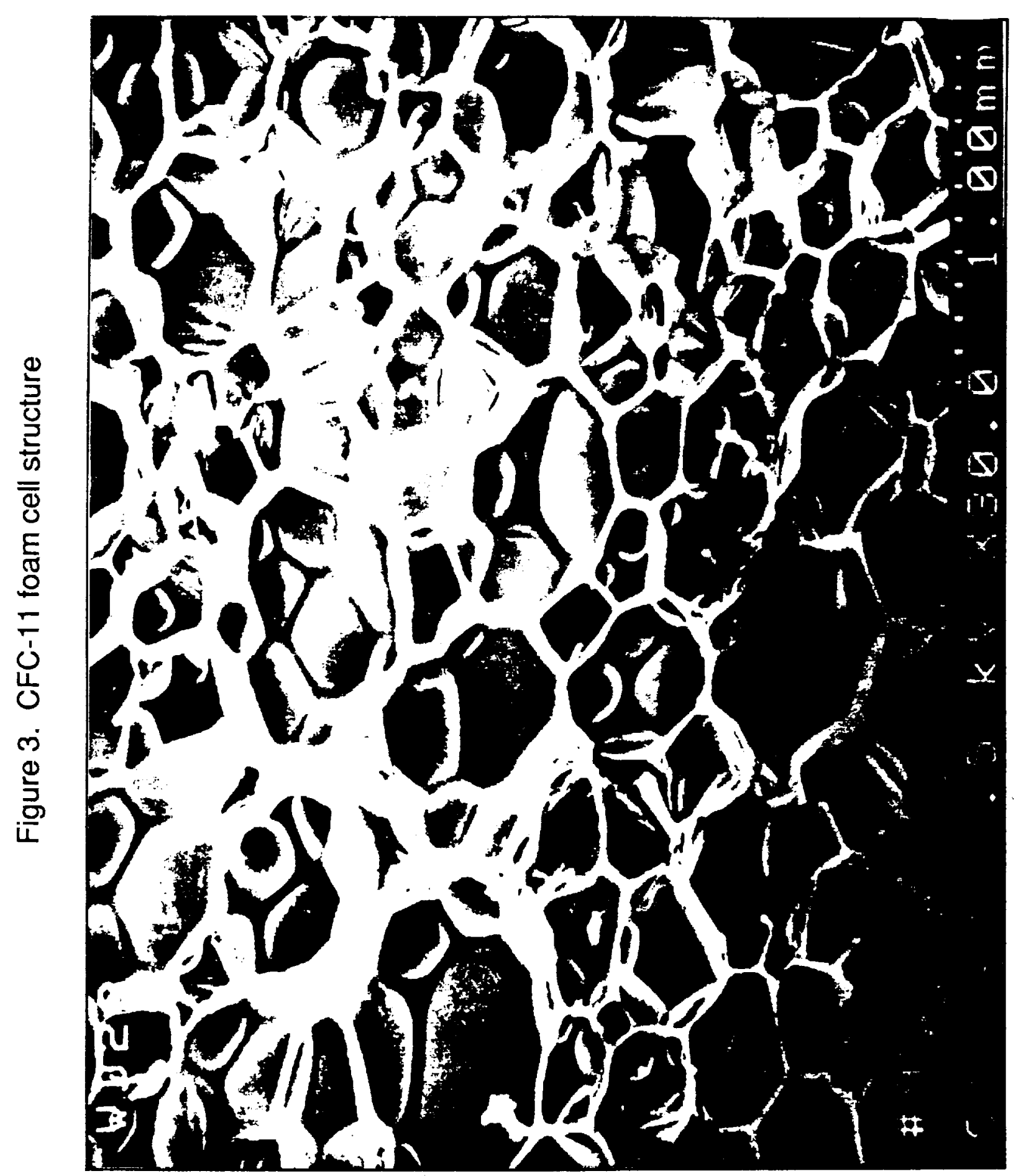




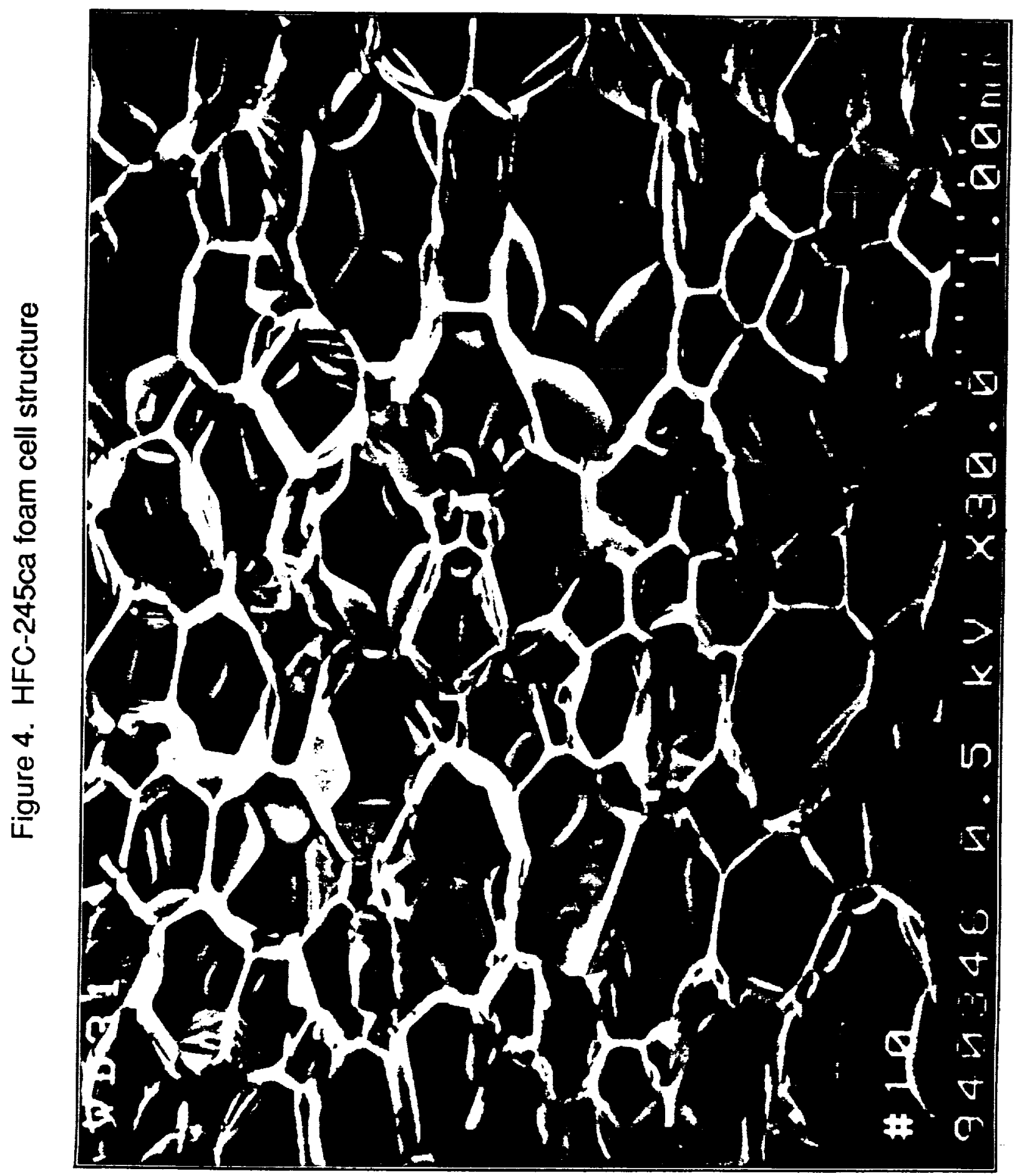




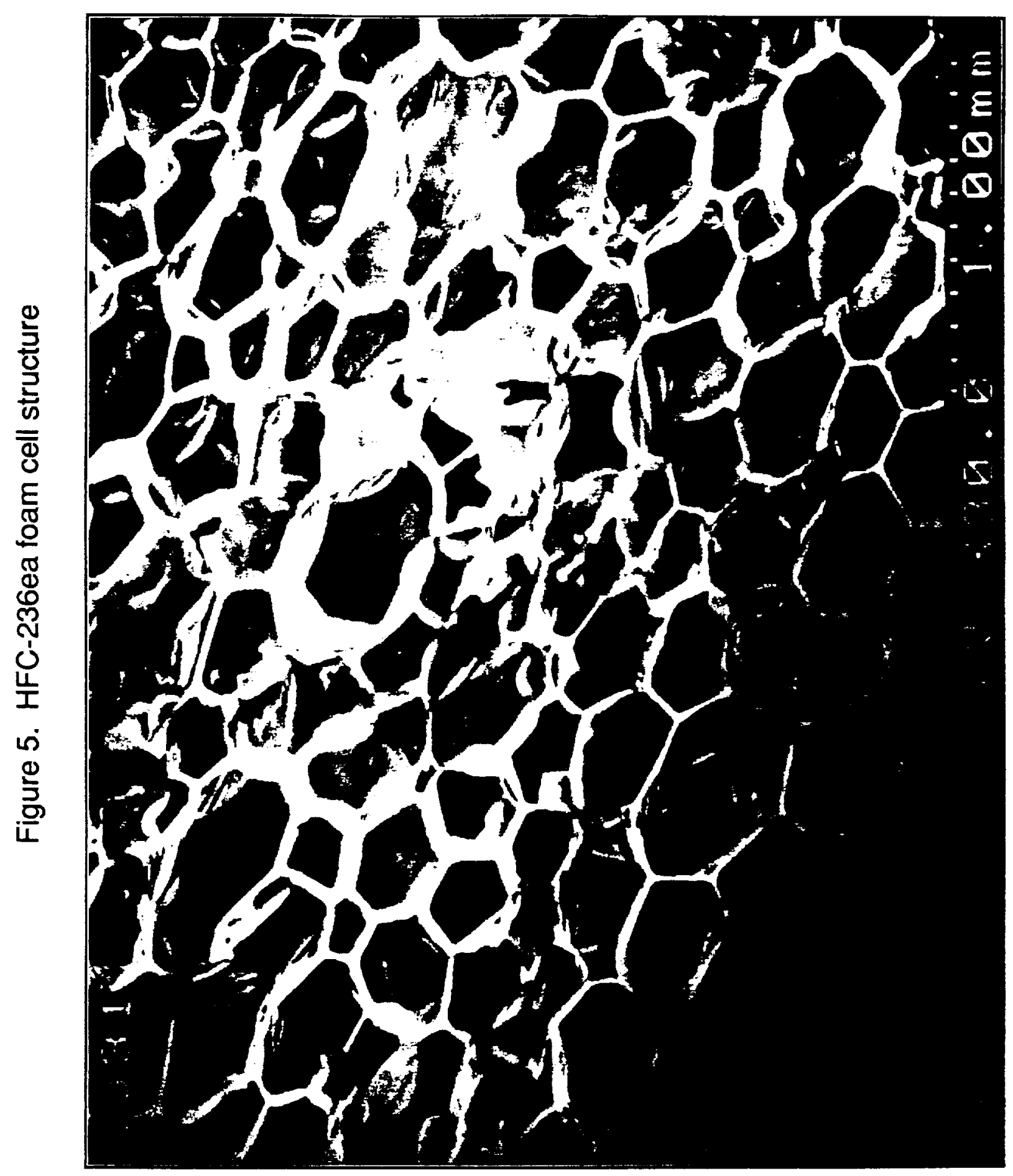




\section{Closed Mold Foam Properties}

Closed mold test panels were also prepared with each of the three foam systems. These test panels consisted of a $14 \times 24 \times 2$ in. mold into which a 0.125 in. thick aluminum test panel was placed for evaluation of foam adhesion characteristics. Mold/panel temperatures of $72^{\circ} \mathrm{F}$ and $115^{\circ} \mathrm{F}$ were evaluated. Table 5 presents the results of the panels prepared with a mold and panel temperature of $72^{\circ} \mathrm{F}$.

Table 5. Closed Mold Foam Properties, $72^{\circ} \mathrm{F}$ Mold and Panel Temperature

\begin{tabular}{l|c|c|c}
\hline \hline Property & CFC-11 & HFC-245ca & HFC-236 ea \\
\hline \hline Core Density, lb/ft ${ }^{3}$ & 2.10 & 1.95 & 2.12 \\
Compressive Strength, lb/in' & 17 & 15 & 21 \\
Bond Tensile Strength* (ambient), lb/in' & 42 & 46 & 40 \\
Bond Tensile Strength $\left(-320^{\circ} \mathrm{F}\right), \mathrm{lb} / \mathrm{in}^{2}$ & 42 & 37 & 13 \\
Bond Tensile Strength $\left(200^{\circ} \mathrm{F}, \mathrm{lb} / \mathrm{in}^{2}\right.$ & 27 & 28 & 17 \\
Flatwise Tensile Strength ${ }^{* *}$ (ambient), lb/in ${ }^{2}$ & 39 & 44 & 47 \\
Friability, \% mass loss & 2.5 & 1.7 & 1.8 \\
\hline
\end{tabular}

* Test of foam adhesion to aluminum substrate

** Cohesive strength of the foam, parallel to rise

The cohesive strength of the three materials was comparable, with the HFC-245ca and HFC-236ea actually exhibiting slightly higher values than the CFC-11 control. Bond adhesion values to an aluminum substrate were also comparable when tested at ambient temperature; however, the HFC-245ca exhibited a coarse, high density layer approximately $1 / 8$-in. thick adjacent to the aluminum substrate. Approximately $65 \%$ of the specimens failed in this region. Almost all of the HFC-236ea foam ambient tensile specimens failed at the substrate interface, leaving a thin polymer residue on the substrate surface. This characteristic is probably due to the short cream time and resulting poor wetting of the substrate with this lower boiling blowing agent. Further formulation development could probably overcome this issue. When tested at low $\left(-320^{\circ} \mathrm{F}\right)$ and elevated $\left(200^{\circ} \mathrm{F}\right)$ temperatures, the bond adhesion of the HFC-245ca compared favorably to CFC-11, while the HFC-236ea foam suffered a significant loss of adhesion.

Because the HFC-245ca foam samples prepared at $72^{\circ} \mathrm{F}$ mold and panel temperature exhibited a coarse, high density layer adjacent to the substrate, it was suspected that the heat sink effect of the aluminum panel contributed to this high density layer. Increased mold and panel temperature panels were prepared in an attempt to resolve this issue. Results of the testing performed at $115^{\circ} \mathrm{F}$ mold and panel temperature, presented in Table 6, did not support this hypothesis. Bond adhesion of all three foams was significantly lower than those prepared at $72^{\circ} \mathrm{F}$ mold and panel temperature. The flatwise tensile strength of the CFC11 and the HFC $-245 \mathrm{ca}$ prepared at $115^{\circ} \mathrm{F}$ was comparable to the values obtained from panels prepared at $72^{\circ} \mathrm{F}$. The HFC-236ea, however, suffered a significant loss of both flatwise tensile strength and bond adhesion. Apparent closed cell content of these foam samples was also determined. The CFC-11 and HFC-245ca, while somewhat lower than optimum, were comparable at approximately $88 \%$. The closed cell content of the HFC-236ea foam could not be determined due to drift in the air pycnometer. This would indicate that this foam has very permeable cell walls or widely distributed ruptured cells/open cell structure. More development work to optimize both the formulation and the application process could help overcome these issues. 
Table 6. Closed Mold Foam Properties, $115^{\circ} \mathrm{F}$ Mold and Panel Temperature

\begin{tabular}{l|c|c|c}
\hline Property & CFC-11 & HFC-245ca & HFC-236ea \\
\hline Density, lb/ $\mathrm{ft}^{3}$ & 1.9 & 1.8 & 1.8 \\
Compressive Strength, Ib/in2 & 17 & 19 & 21 \\
Bond Tensile Strength* (ambient), lb/in' & 13 & 14 & 30 \\
Flatwise Tensile Strength, lb/in ${ }^{2}$ & 44 & 47 & 28 \\
Closed Cell Content, \% & 88 & 88 & $\mathrm{ND}^{* *}$ \\
Limiting Oxygen Index, \% $\mathrm{O}_{2}$ & 21 & 19 & 19 \\
\hline
\end{tabular}

* Test of foam adhesion to aluminum substrate

** No data

THERMAL AND AGING CHARACTERISTICS

Thermal conductivity of molded panels $(k)$ was also determined, both in the laboratory and independently by Oak Ridge National Laboratory (ORNL).

Thermal conductivity of molded foam samples was performed in the foam laboratory using an Anacon TCA 8 thermal conductivity analyzer. Results of this testing are presented in Figure 6. These data indicate that both the HFC-245ca and the HFC-236ea had initial thermal conductivities approximately $24 \%$ higher than CFC-11 (0.149 Btu-in/hr- $\mathrm{ft}^{2}-{ }^{\circ} \mathrm{F}$ versus $\left.0.120 \mathrm{Btu}-\mathrm{in} / \mathrm{hr}-\mathrm{ft}^{2}{ }^{\circ} \mathrm{F}\right)$. In these samples, the HFC-245ca appeared to be aging at a similar rate to CFC-11 while the HFC-236ea appeared to age much faster.

Molded panels were supplied to ORNL for determination of apparent thermal conductivity and a preliminary assessment of aging characteristics. For determination of apparent thermal conductivity and accelerated aging, the technique used by ORNL involves determination of thermal conductivity of a single full thickness test panel and, separately, determination of thermal conductivity of a stack of thin (3/8-in.) core slices from four panels. These test values are typically plotted as natural logarithm of 100 times the conductivity (1n 100k) versus the square root of the aging time divided by the foam thickness. This results in linear regions with respect to foam age that can be useful in forecasting long term performance. In the model ORNL has developed, the full thickness test panel results typically compare closely to the thin slice results.

Test results from the foam panels prepared for this study are shown in Figures 7 through 9. Each graph shows results of both the full thickness panel tests and the stacked thin slice tests. The full thickness and stacked thin slice values tracked very well for both the HFC-245ca and HFC-236ea, but the CFC-11 full thickness panel results did not compare well to the thin slice results. Inspection of the CFC-11 full thickness panel revealed that it had a coarse, non-uniform cell structure and was probably not representative of actual material performance. This observation is being confirmed with additional testing. Thus, for the CFC-11, the thin slice data are believed to be a better basis for comparison. With this disparity in mind, a cursory relative comparison of the trend between the CFC-11 thin slices and the HFC-245ca and HFC-236ea data can be made.

The thin sliced CFC-11 panels had an initial thermal conductivity of $0.1251 \mathrm{Btu}-\mathrm{in} / \mathrm{hr}-\mathrm{ft}^{2}{ }^{\circ} \mathrm{F}$, increasing to $0.1583 \mathrm{Btu}-\mathrm{in} / \mathrm{hr}-\mathrm{ft}^{2}{ }^{\circ} \mathrm{F}$ after 64 days of aging. The HFC-245ca thick panel exhibited an initial $\mathrm{k}$-value of $0.1453 \mathrm{Btu}-\mathrm{in} / \mathrm{hr}-\mathrm{ft}^{2}{ }^{\circ} \mathrm{F}$, which increased to $0.1522 \mathrm{Btu}-\mathrm{in} / \mathrm{hr}-\mathrm{ft}^{2}{ }^{\circ} \mathrm{F}$ after 43 days of aging. The initial $\mathrm{k}$-value of the thick HFC-245ca panel and the thin sliced panels differed by $2 \%$. Overall, the HFC-245ca foam aging trend appeared to parallel that of the CFC-11 foam, but with values averaging $20 \%$ higher than those of the CFC-11 foam. 


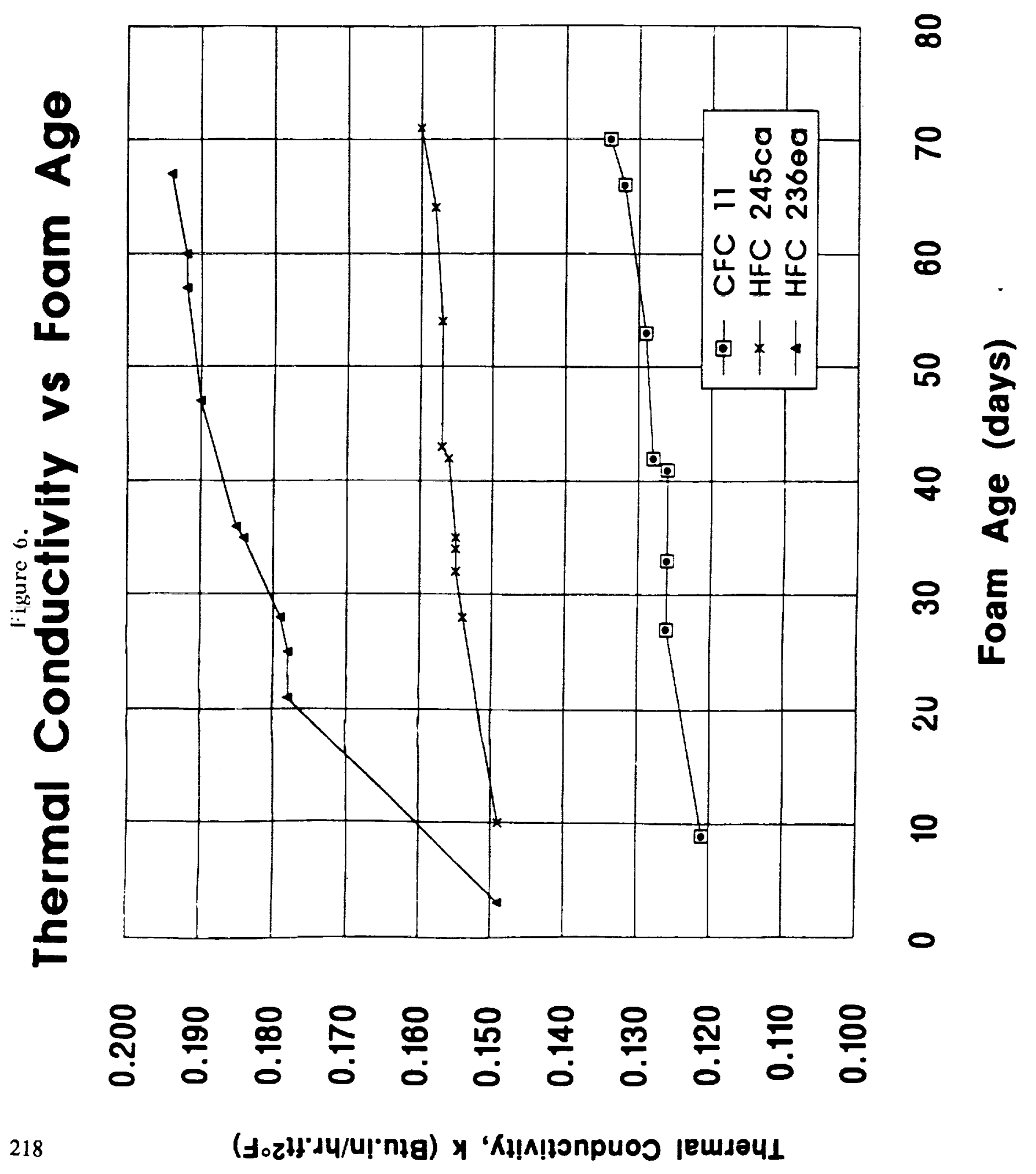




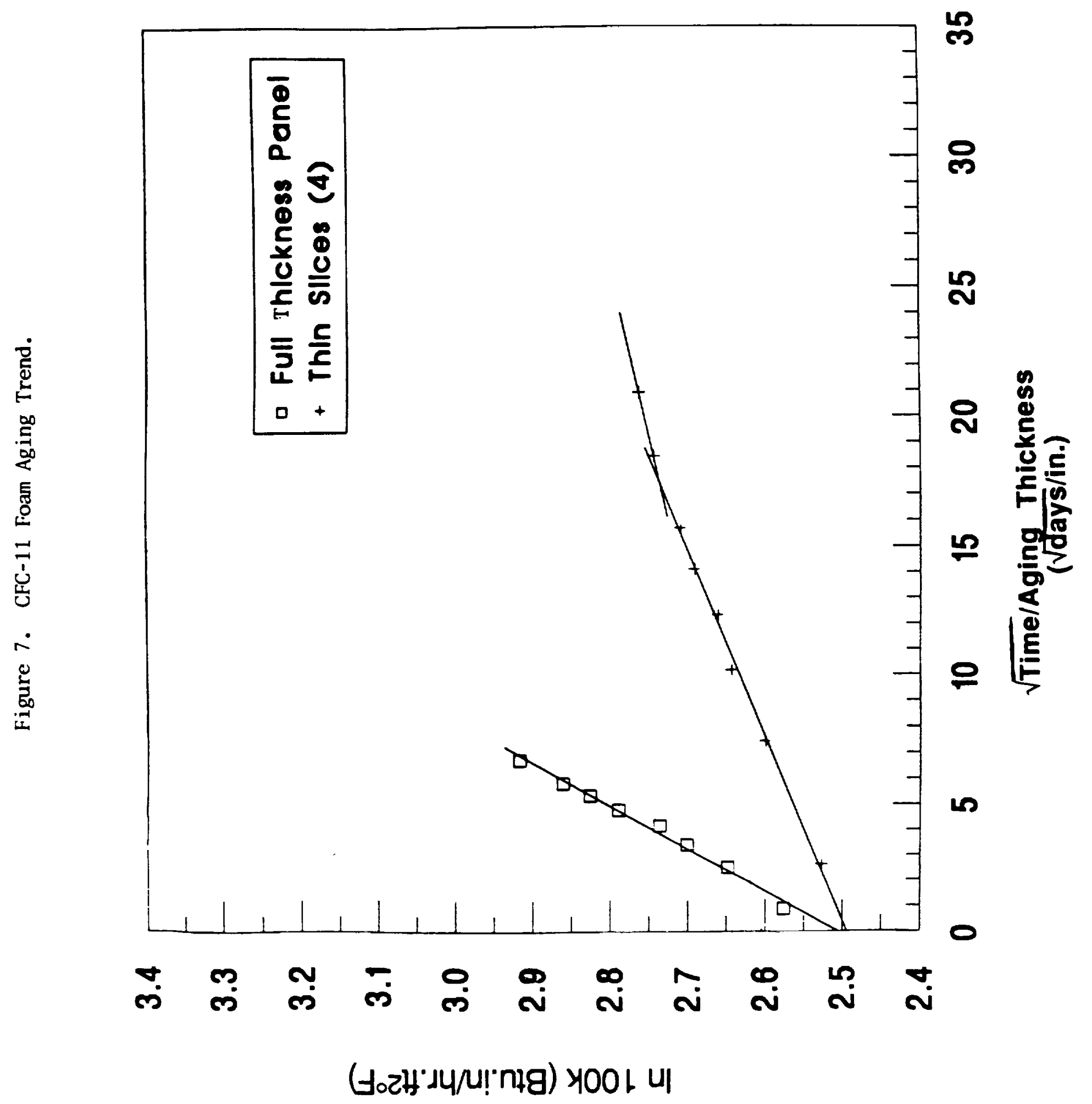




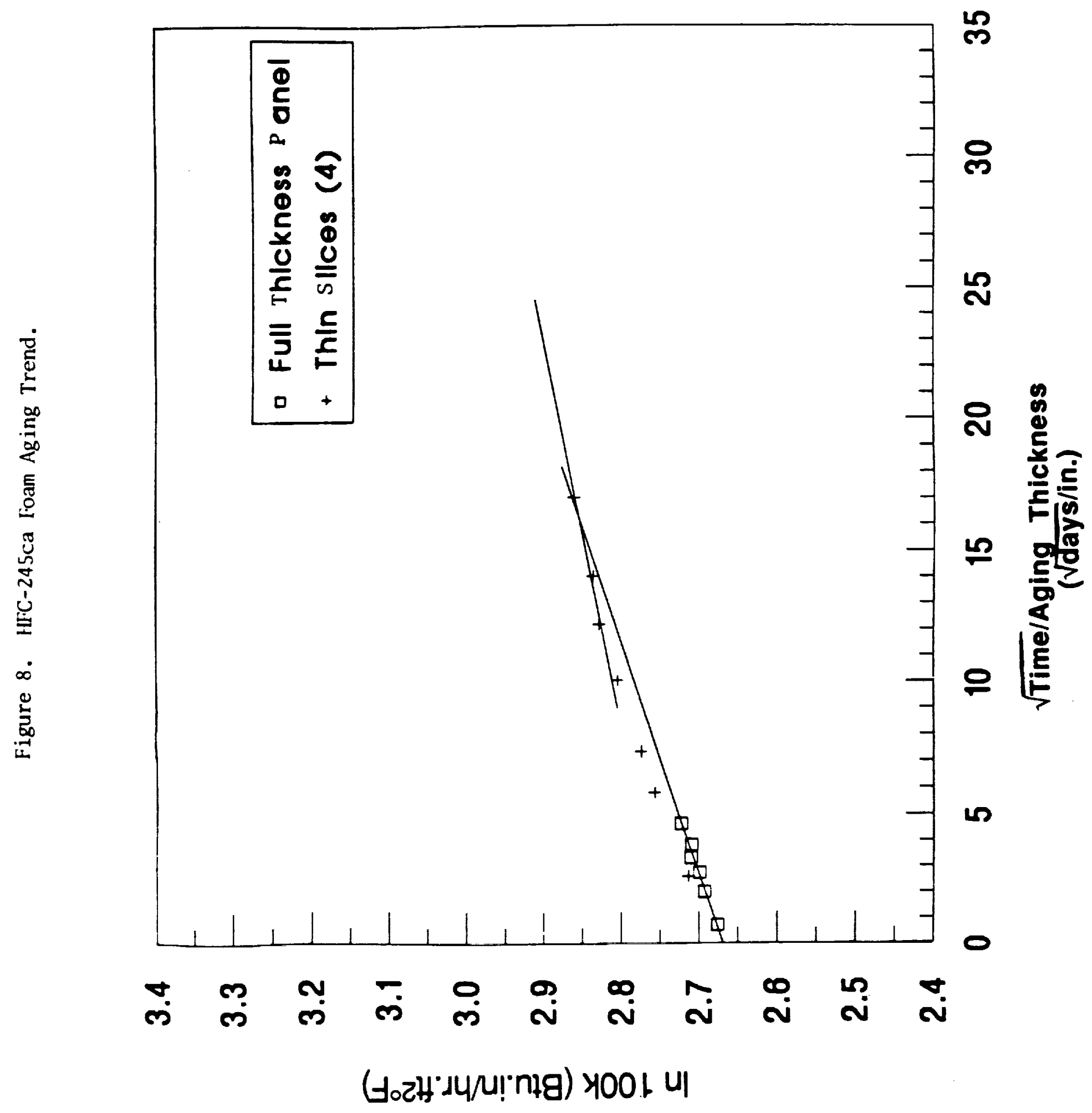




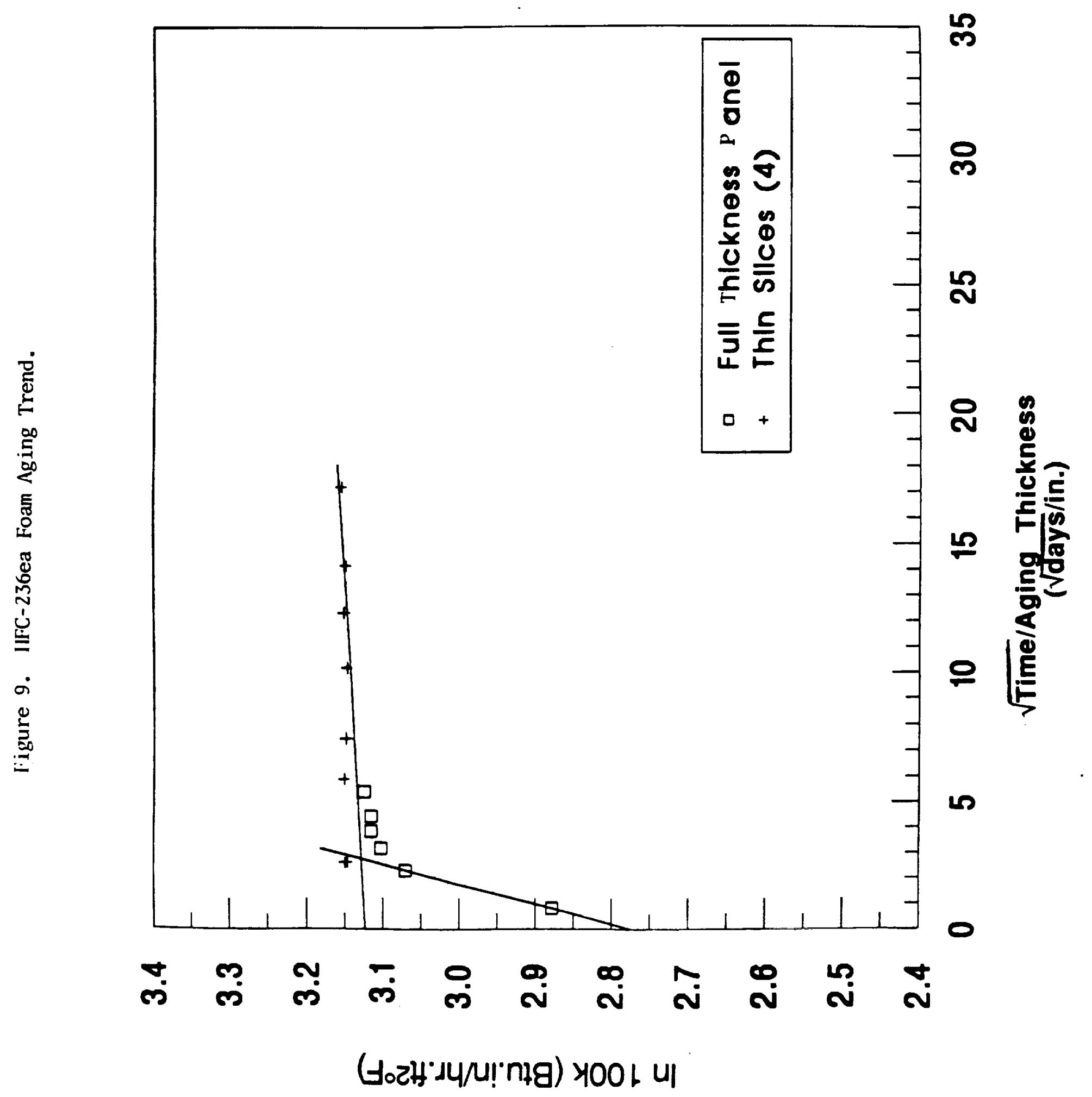


The HFC-236ea thick panel had an initial k-value of $0.1778 \mathrm{Btu}-\mathrm{in} / \mathrm{hr}-\mathrm{ft}^{2} \mathrm{o}$, increasing to $0.2278 \mathrm{Btu}-$ in $/ \mathrm{hr}-\mathrm{ft}^{2}{ }^{\circ} \mathrm{F}$, after 43 days of aging. The thin sliced panels appeared to be completely aged at day 1 . They exhibited an initial $\mathrm{k}$-value of $0.2333 \mathrm{Btu}$-in/hr-ft ${ }^{2}{ }^{\circ} \mathrm{F}$, increasing to $0.2348 \mathrm{Btu}$-in/hr-ft ${ }^{\circ} \mathrm{F}$, after 43 days of aging. This would indicate that the HFC-236ea foam had a relatively open cell structure (supported by attempts to determine closed cell content) and/or that the HFC-236ea diffuses quickly from the foam. More studies will help understand and compensate for this characteristic.

\section{CONCLUSIONS}

Both HFC-245ca and HFC-236ea have been compared to CFC-11 as blowing agents in a simple, nonoptimized urethane formulation. Both materials have been shown to have potential as foam blowing agents should they become commercially viable.

The HFC-245ca foam exhibited similar handling characteristics and reactivity to the CFC-11 control. The boiling point and solubility of this material make it easy to blend and hand pour using conventional techniques. Mechanical and physical properties of the HFC-245ca foam were also comparable to CFC-11 except that the HFC-245ca foam exhibited a coarse, high density layer adjacent to the substrate. Also, the HFC-245ca foam exhibited an initial thermal conductivity approximately 16 to $22 \%$ higher than the CFC11 control. These results indicate that HFC-245ca should be relatively easy to process using conventional equipment, but that changes in formulations may be required to approach equivalent insulation or adhesion characteristics (or other properties) compared to CFC-11 foam.

The HFC-236ea blown foam was somewhat more difficult to prepare due to the lower boiling point of the material and resulting tendency to froth when mixed at ambient conditions. This characteristic resulted in poor wetting and adhesion to the aluminum substrate evaluated in this study. Additionally, the initial thermal conductivity of the foam prepared with HFC-236ea was between 23 and $44 \%$ higher than that of CFC-11 and it aged very quickly to a thermal conductivity approximately $50 \%$ higher than the CFC-11 foam. These characteristics indicate that considerable more effort will be required to optimize a foam formulation and/or process to achieve satisfactory results with HFC-236ea as the sole blowing agent.

\section{ACKNOWLEDGEMENTS}

This work was funded by the External Tank Project of the National Aeronautics and Space Administration under contract NAS8-36200 with Martin Marietta Manned Space Systems; the Building Systems and Materials Division, Office of Buildings Energy Research, U.S. Department of Energy, under contract number DE-AC05-840R21400 with Martin Marietta Energy System; and the U.S. Environmental Protection Agency under Interagency Agreement DW89934975 with the U.S. Department of Energy.

The authors wish to thank Brigitte Parker and Allen Ivey for their support in the preparation and testing of foam samples, and Jim Abouseadah and Martha $\mathrm{O}^{\prime} B$ Brien for preparing the illustrations and manuscript.

\section{REFERENCES}

1. Phase-Out of Ozone Depleting Substances, Federal Register 58 FR 65018, 40 CFR Part 82, December $10,1993$.

2. Beyerlein, A. L., D. D. Des Marteau, S. H. Hwang, N. D. Smith, and P. A. Joyner, "Physical Properties of Fluorinated Propane and Butane Derivatives as Alternative Refrigerants," ASHRAE Transactions 1993, v.99, PL.1. 
3. Smith, N. D., "New Chemical Alternatives for CFCs and HCFCs," EPA-600/F-92-012, March 1992.

4. Knopeck, G.M., R. C. Parker, R. G. Richard, and I. R. Shankland, "Evaluation of Next Generation Blowing Agents," Polyurethanes World Congress 1993, p. 465.

\section{CONVERSION TABLE}

\begin{tabular}{l|l|l}
\hline British & Multiplied By & Yields Metric \\
\hline & & \\
${ }^{\circ} \mathrm{F}$ & $5 / 9\left({ }^{\circ} \mathrm{F}-32\right)$ & ${ }^{\circ} \mathrm{C}$ \\
in. & 0.0254 & $\mathrm{~cm}$ \\
$\mathrm{lb} / \mathrm{ft}^{3}$ & 16.02 & $\mathrm{~kg} / \mathrm{m}^{3}$ \\
$\mathrm{lb} / \mathrm{in}^{2}$ & 0.0703 & $\mathrm{~g} / \mathrm{cm}^{2}$ \\
Btu/lb-mol & 2.325 & $\mathrm{~J} / \mathrm{g}-\mathrm{mol}$ \\
Btu-in/hr-ft ${ }^{2}{ }^{\circ} \mathrm{F}$ & 0.1442 & $\mathrm{~W}-\mathrm{cm} / \mathrm{m}^{2-}{ }^{\circ} \mathrm{C}$
\end{tabular}

\section{BIOGRAPHIES}

Ron Graves is a research staff member in the Materials Thermal Analyses Group at the Oak Ridge National Laboratory working in the field of energy conservation materials. He attended the University of Tennessee prior to joining ORNL in 1958. He is a member of the American Society for Testing and Materials and is a Fellow in the International Thermal Conductivity Conference. Ron has done research on building insulations for about 16 years and is author or coauthor on numerous papers and reports on the testing and properties of thermal insulations.

Robert V. Hendriks received his B.S. degree in Pulp and Paper Technology from N.C. State University, M.S. degree in Chemical Engineering from Clemson University, and M.B.A. degree from Duke University. He is a Senior Research Engineer with the Environmental Protection Agency, Air and Energy Engineering Research Laboratory in Research Triangle Park, N.C. His current responsibilities involve development of environmentally acceptable alternative refrigerants and foam blowing agents.

Tom Kollie is the Group Leader of the Materials Thermal Analyses Group at the Oak Ridge National Laboratory. The Group measures and analyzes heat transport in materials. Tom received his M.S. and Ph.D. degrees in Metallurgical Engineering from the University of Tennessee in 1965 and 1969, respectively, and a B.S. in Ceramic Engineering from the Georgia Institute of Technology in 1959. He is a member of ASTM and ASM International. For the past 35 years, Tom has performed research and development on physical properties of materials, thermometry, alloy development, and advanced thermal insulations.

Matthew Liu is a staff Material Scientist with Martin Marietta in New Orleans, Louisiana, where he has been employed since 1975. His educational background is in Polymer Science from the University of Akron in Ohio. His professional interest is in the development of materials, including foams, coatings, primers, and adhesives. Matt is the co-author of several papers and patents and is currently involved in zero ODP blowing agent development and PU/PIR foam catalyst system investigation for cryogenic applications. 
Doug MacArthur graduated from Eastern Michigan University in 1965 with a B.S. in Biology. Since 1967 he has held various technical positions in the polyurethane industry in the United States, Australia, and Canada. In 1983 he joined Martin Marietta. He is currently responsible for developing zero ODP blowing agent foam systems for use on the External Tank of the Space Shuttle at the Marshall Space Flight Center in Huntsville, Alabama.

Jon Sharpe received his B.S. degree in Chemical Engineering from the University of Alabama and M.S. degree in Engineering Management from Florida Institute of Technology. He is Manager of Development and Test Engineering at Martin Marietta's Marshall Space Flight Center Operations in Huntsville, Alabama. His current responsibilities include development and testing of materials for cryogenic and high heat applications for use on the External Tank of the Space Shuttle. 